\title{
CORPORATE DISTRIBUTIONS TO STOCKHOLDERS
}

\author{
VERN KRISHNA*
}

\begin{abstract}
The intricacy of corporate taxation, since the advent of the new legislation in 1972, is now accepted as a fact of life. In this article, Mr. Krishna explains the legal, accounting and economic policy implications of three related areasdesignated surplus, pre-1972 surplus, and post-1972 surplus distributions. The article examines and evaluates the numerous interrelated variables to be considered in determining the timing and desirability of special and ordinary dividends. Various planning devices are suggested in the article, together with an outline of the pitfalls which await the unwary.
\end{abstract}

\section{INTRODUCTION}

The area of corporate taxation is of interest to Canadians, and others, in virtually every sphere of economic activity in Canada. The structure of Canadian economic activity embraces the Federal and Provincial governments in Canada in their planning and control activities. At both levels of administration, planners are called upon to render legislation which will enhance the economic prosperity of Canadians, generate fiscal policies, and monitor the efficacy of such policies. Concurrently with these tasks, corporate planners seek means to digest the volume of complex and intricate legislation in the sphere of taxation.

This paper examines a small segment of corporate tax issues raised by the new Income Tax Act. ${ }^{1}$ Specifically, it analyzes the problems raised in the areas of designated surplus, pre-1972 corporate surplus distributions and post-1971 surplus extractions. At the same time, it endeavours to explain the policy rationale behind the legislative enactments in the above-mentioned areas of the law, together with the planning implications generated by the new Act.

\section{DESIGNATED SURPLUS}

\section{Nature of Problem}

Corporate surplus has traditionally posed a major problem for corporate tax planners and governmental policy planners. Underlying the problem of corporate surplus are the two conflicting goals of these two divergent interests. On the one hand, individual taxpayers are invited to leave funds in the corporate organization as a consequence of progressive personal tax rates. This route is advantageous for shareholders who may thereby defer tax or, alternatively, dispose of their holdings for capital gains. On the other hand, fiscal theory requires encouragement for distribution of such funds, both for the purpose of revenue generation and reinvestment of such funds in the economic system.

Two principal reasons may be observed for the incentive behind taxpayers' schemes to extract corporate surpluses:

(a) The absence of full integration of corporate and personal taxes induces shareholders of private corporations to extract any surplus free of tax. While shareholders of public companies have available

\footnotetext{
-B.Comm., M.B.A., C.G.A., LL.B. I am deeply indebted to Professor Frank D. Jones, Faculty of Law, University of Alberta, for his encouragement and critical review of this paper.

I R.S.C. $1970-71 \cdot 72$, c. 63.
} 
to them the option of disposing of their holdings for capital gains, this avenue is generally unavailable to shareholders of private companies, or, where available, the opportunities are restricted. ${ }^{2}$

(b) The preferential treatment accorded to capital gains where the effective tax rate for individuals in the highest tax brackets is approximately $31 \%$ as opposed to a rate of $47 \%$ on dividend income. ${ }^{3}$

\section{Historical Perspective}

To circumvent the imposition of taxes on the distribution of corporate surpluses, taxpayers devised techniques of "dividend stripping". In order to appreciate the devices employed by corporate tax planners and the feverish efforts of the Department to thwart such efforts, it is essential to provide a brief historical survey of the techniques devised.

Dividend stripping, in its most simplistic form, is a process whereby a corporation strips an acquired corporation's surplus free of the payment of tax. The entire process was facilitated by the equivalent of $s .112(1)$ of the Income Tax Act allowing for tax free inter-corporate dividends, and was designed to prevent the multiple taxation of inter-corporate dividends. Prior to 1950, the scenario would be as follows: A shareholder controlling Co. A, which company had a surplus of $\$ 500,000$, would cause a second company, Co. $\mathrm{X}$, to be incorporated. The shareholder would sell his holdings to $\mathrm{Co}$. $\mathrm{X}$ in return for a note. Co. A would pay a dividend of $\$ 500,000$ to Co. $X$, which dividend would be tax free by virtue of the equivalent of s. 112(1). Thereupon, Co. X would pay off its note to the individual shareholder. By this process, the individual shareholder would have received a capital gain (non taxable prior to 1972, and taxable at preferential rates since) and Co. A would have been stripped of its surplus.

To prevent such corporate extractions, the concept of "designated surplus" was introduced. In essence, "designated surplus" is the undistributed income on hand of a corporation at the time control of the corporation changes. The surplus is, in effect, "designated" at the time of control change by s. 192(13). Once the surplus became "designated", it was no longer eligible for tax free treatment of inter-corporate dividends. Confronted with this new concept of designated surplus, corporate tax planners devised new techniques to extract such surpluses tax free. Three principal variations were designed to accomplish this objective:

(a) The sale of shares to a corporation that was not taxable under the equivalent of s. 149. In view of the non taxability of such entities, the penalty of non-deductibility of such intercorporate dividends to the receiving corporation was ineffective.

(b) The "Broker Bail Out"-This variation called for the sale of shares to a broker, who would generate a tax loss and pipeline the extracted designated surplus on to the individual shareholder free of tax. Since the broker was involved in the business of buying and selling securities, he could write off his loss on the trans-

\footnotetext{
- The Companies Act, R.S.A. 1970, c. 60, s. 2(26); Canada Corporations Act. R.S.C. 1970, c. 70, s. 341).

- The exact percentage will vary according to the residence of the individual in different provinces.
} 
action. The broker received his compensation in the form of a commission for handling the transaction. ${ }^{4}$

(c) Holding companies-Concurrent with the introduction of the concept of designated surplus was the creation of the notion of "control period earnings". Since dividends paid out of control period earnings were not subject to the restrictions and penalties imposed on dividends from designated surplus, tax planners recruited the assistance of holding companies. In this scheme, a shell holding company was interposed between the company having undistributed income and the final recipient corporation. Since control of the company with a surplus never changed, the surplus could be extracted under the guise of control period earnings. 5

\section{Current Provisions}

In order to close the above-mentioned "loopholes", the 1972 Income Tax Act introduced several new provisions. The basic concept of designated surplus, as defined in s. 192(13), remains the earnings retained in the corporation at the time of control change. However, 8. 192(4) closes the "loophole" in regard to holding companies. Now control is deemed to exist where a new corporation takes control, or takes control of other persons who have control of the corporation with the surplus,

Further, the problem of dividend stripping is now controlled by Parts VII and VIII of the Income Tax Act. By virtue of s. 192(1), a special $\operatorname{tax}$ of $25 \%$ is imposed on dividends received from a controlled corporation's designated surplus. While the dividend is still deductible under 8. $112(1)$, it is subject to the special tax. Thus, where a dividend of $\$ 50,000$ is received by Co. A from Co. B's designated surplus, the following would result:

\begin{tabular}{lc} 
Income of Co. A & $\$ 50,000$ \\
S. 112(1) deduction & $(50,000)$ \\
\cline { 2 - 2 } Taxable Income & 0 \\
Tax Payable & 0 \\
Special Tax under 8. 192(1) at 25\% & 12,500 \\
& $\$ 37,500$ \\
Net After Tax & $\$$
\end{tabular}

Two facets of this special tax are worthy of note. First, the special tax under s. $192(1)$ is payable by the receiving corporation. Second, the dividend so received will reduce the adjusted cost base of shares held under s. 53(2)(a)(ii).

Again, under s. 194(1), where a dividend is paid out of designated surplus to a non resident corporation, then a special tax of $15 \%$ is levied on the payor corporation. Hence, after accounting for the withholding tax, the effective rate of tax is approximately $27 \%$. By virtue of the same provision, if the dividend from designated surplus is paid to a tax exempt organization, e.g., a charity under 8. 149, a special tax of $33-1 / 3 \%$ must be paid by the payor corporation. This effectively works out to $25 \%$ of the total amount paid out by the company. For example: 
Dividend paid

S. 194(1) tax

Total paid out by Co.
$\$ 75,000$

25,000

To further strengthen the Department's position, s. 247 provides the Minister of National Revenue with discretion to impose a further tax, if "... in the opinion of the Minister ..." the purpose was to effect a substantial reduction of, or disappearance of, the assets of a corporation.

\section{Policy Implications}

The policy and rationale behind the imposition of Part VII taxes is obvious. They tend to discourage the conversion of potentially taxable surpluses of corporations into capital gains. Rather, if such surpluses were to be distributed to individual shareholders, the entire dividend would be taxable (less any dividend tax credit), whereas only $50 \%$ of capital gains are taxable as income. Thus, the intricate and complex provisions of the designated surplus provisions are justified by the Department on the basis of a $17 \%$ differential in tax between top marginal rates for capital gains and dividend income. ${ }^{6}$ In these circumstances, it may be argued that the potential revenue loss does not appear to justify the retention of $s .247(1)$.

However, while the policy may be obvious, the consequent implications are not nearly as conspicuous. It is submitted that the provisions pertaining to designated surplus are framed in the wrong manner. For one thing, the rules do not prevent forward stripping by paying off the purchase of shares through future earnings. For another, the provisions are directed towards the wrong person. The provisions as drafted are orientated at the purchaser of shares, rather than the vendor who has avoided the tax. ${ }^{7}$

A further drawback of the existing provisions is the s. 247 discretion afforded the M.N.R. As observed earlier, this provision enables the M.N.R. to collect taxes which he believes have been avoided through technicalities. While the provision may reflect the frustrations experienced by the Department in coping with dividend stripping in its various guises, it has the ancilliary effect of generating uncertainty until an assessment has been issued. This may occur at some future time, perhaps as distant as four years after the alleged reduction or disappearance of assets. ${ }^{8}$ The legislation, thus, has an inhibiting effect on proposed transactions, which may not have, as their primary purpose, the intention to dividend strip. In the result, every time a corporation acquires a substantial interest in another corporate entity, the vendor may become subject to tax because of some action taken by the purchaser, over whom he has no control! 9 It is worthy of note that even where s. 247 has been applied to levy tax, there is no assurance that at a later date s. 192(1) may not be applied to tax the same undistributed income.

The consequent net effect of these provisions may well be that they succeed in interfering with desirable reorganizations and rationaliza-

\footnotetext{
- Swirsky, 1972 Conference Report 45.

Id. at 46 .

*S. 152(4)

4 Reports of the Royal Commission on Taxation 606 (1966).
} 
tions of corporate arrangements. ${ }^{10}$ If such be the case, then, as the Carter Commission observed: ${ }^{11}$

.. of considerable importance is the probability that the continued existence of widespread avoidance in this area will bring the entire tax system into such disrepute as to undermine the principles of self-assessment and voluntary compliance which form the foundation on which it operates ...

In addition to the implications related above, the following further consequences and effects are worthy of consideration:

(a) If the statutory provisions, outlined above, lead to a policy of capital retention, the result may well be that the capital markets become thinner than desirable. ${ }^{12}$

(b) Whereas shareholders of public corporations can sell their shares, and thereby realize capital gains due to the retention of earnings, shareholders in private corporations are not in as advantageous a position. By permitting surplus stripping to this latter group, the effect would be to put the shareholders of private companies on the same footing as that of public companies. ${ }^{13}$

(c) The retention of earnings in the corporate entity is a method of avoiding or deferring personal taxes. It amounts to a tax reduction by postponing the tax liability indefinitely and may eventually eliminate it completely. ${ }^{14}$ However, this method is inequitable in that it is only available to some taxpayersordinarily to those who control closely held corporations- and thereby transfers the tax burden to other taxpayers. ${ }^{15}$ To recoup the lost revenues, other taxes will tend to be higher. However, as observed in (b) supra, the effect is, in part, offset by the equalization of positions of the shareholder in public corporations visa-vis a shareholder in a private corporation.

(d) Again, those who control these private corporations are induced to retain more earnings than might otherwise be the case. These incremental savings may tend to be invested less productively as the owner will be willing to accept a lower before tax rate of return than investors who cannot avail themselves of surplus stripping. ${ }^{16}$

\section{Planning Considerations}

In order to cope with these problems of designated surplus, corporate tax planners may consider various steps. First, where a corporate reorganization and/or acquisition is contemplated, it may be prudent to obtain an advance ruling from the Department. While there is a cost involved in obtaining such rulings, the amount involved should be minimal in the context of any substantial acquisition. However, such rulings are given only under the most stringent stipulations as outlined by the Department, and will usually involve a delay of five to six months, thereby minimizing the value of the information.

Second, by virtue of the provisions of s. $196(1)$ and s. $83(1)$, to be considered in depth later in this paper, a corporation can pay $15 \%$ tax on its

\footnotetext{
10 Edwards, 1971 Conference Report 128.

"Supra, n. 9 at 613 .

12 Id. at 4-18.

13 Id. at 4-15.

14 The present value of $\$ 1.00$ at 8 , is $\$ 0.14$ in 25 years and $\$ 0.02$ in 50 years.

1315 Studies of the Royal Commission on Taxation 7 (1966).

16 Id. at 8 .
} 
1971 undistributed income, and distribute this sum "tax free" to the shareholders. The payment of this elective tax permits that amount to be deducted from designated surplus. However, such dividend reduce the adjusted cost base of shares and increase the potential for capital gains in the future.

Third, the above mentioned $15 \%$ tax, under Part IX of the Income Tax Act, may prove to be of some value in the event of a winding up. Where a corporation is being wound up, and has designated surplus on hand, then by virtue of s. 84(2), a taxable dividend is deemed to have been paid and will be subject to Part VII or VIII tax. Hence, the payment of the Part IX tax will reduce this liability. Dividends paid out of either Tax Paid Undistributed Surplus [TPUS], or designated surplus, will reduce the adjusted cost base of shares by virtue of 8 . $53(2)(a)(i)$, (ii) and (iii). ${ }^{17}$

\section{CORPORATE SURPLUS AS AT DECEMBER 31,1971}

\section{Nature of Surplus Accounts}

Turning now to the distribution of TPUS accumulated at the beginning of the new system, one observes that such TPUS is derived from three components parts:

(a) 1971 Undistributed Income on Hand [UIOH] is defined in s. 196(4). Essentially, this amount is the income accumulated by the corporation less any dividends paid out, less tax paid undistributed income. It should be observed that undistributed income and retained earnings are not necessarily one and the same thing. While retained earnings represent the accumulated earnings after providing for tax as shown on the financial statements, undistributed income is a tax term which refers to accumulated taxable income less any income tax actually assessed thereon.

(b) Tax Paid Undistributed Income on Hand [TPUI] was created under the old Act by paying a special $15 \%$ tax under 8. 105. The remaining balance of $85 \%$ represented Tax Paid Undistributed Income on Hand.

(c) Tax Paid Undistributed Surplus consists of TPUI and that portion of $1971 \mathrm{UIOH}$ on which the special 15\% tax under Part IX has been paid.

The rationale of this breakdown of surplus accounts is to provide continuity from the old system, whereby surplus could be distributed free of tax after paying $15 \%$ under s. 105 . The new process, however, is considerably simpler than the old s. 105 system.

1971 surplus accounts are governed by Part IX of the Act, specifically s. 196 and s. 197 . S. 196 provides the initial step in distributing the retained earnings of a corporation for the period 1950 to 1971 at a tax cost of 15\%. Upon computation of 1971 UIOH and payment of $15 \%$ tax under Part IX, the residue becomes part of TPUS. ${ }^{18}$

Once TPUS has been created in the manner described above, it may be distributed to shareholders "free of tax," by electing under s. 83(1). It is worthy of emphasis that the provisions of $\mathrm{s}$. 83(1) are elective, and any such election must be made in the prescribed manner. There

\footnotetext{
1 Ewens, The Winding Up of (orporatiuns (Mhorusise Than Linder Siction sk. 2I ('an. Tax J. at 9.
}

1n The method of computation is outlined in I'T.tiok. 
is no compulsion on a corporation to distribute its TPUS. Further, the use of the phrase "free of tax" is somewhat of a misnomer, in that the dividends received from TPUS reduce a shareholder's adjusted cost base [ACB] under s. 53(2)(a)(i). The rationale behind this is that such dividends are treated as a return of investment as of the end of 1971, and presumably reduce the value of outstanding shares, which may or may not be true, depending on the technique of valuation. Hence, the term "tax deferred" is perhaps a more accurate portrayal of the transactions described above.

\section{Alternative Available}

Given this avenue for the distribution of corporate surpluses, under what circumstances is it attractive to pay a dividend out of TPUS as opposed to an ordinary taxable dividend? The answer is dependent upon four factors:

(a) the marginal rate of tax of the individual shareholder;

(b) the holding period over which the shareholder is likely to retain his shares;

(c) the capital structure of the entity; and

(d) the cash flow of the corporation.

\section{(a) Marginal Rate Factor}

As a rule, if a taxpayer's marginal rate of tax is in excess of approximately $37 \%$ i.e., at a taxable income of approximately $\$ 25,000$, it would be to his advantage to receive a dividend out of TPUS rather than an ordinary taxable dividend. This is demonstrated in the computation below:

\section{Special s. 83 Dividend}

$1971 \mathrm{UIOH}$

Less: $15 \%$ 8. 196(1) Tax

TPUS distributed tax free

Dividend Paid

Taxable Dividend

Dividend Tax Credit

(Federal and Provincial) ${ }^{19}$

Tax Payable by shareholder at $37 \%$

Net After Tax Proceeds

It should be observed that failure to pay the $15 \%$ tax when making the election renders the election null and void under $8.197(1)$.

\section{(b) Holding Period Factor}

As observed earlier in this paper, dividends paid out of TPUS are not really "tax free" since the ACB of shares is reduced by virtue of 8 . $83(1)(d)$ and s. 53(2)(a)(i). The effect of this reduction in the ACB of shares is illustrated below:

\footnotetext{
19 The dividend tax credit is calculated on the short form basis, rather than taking $4 / 5$ of the gross as required under s. 121. The resulting inaccuracy is minimal.
} 
Dividend paid out of 1971 UIOH

Part IX tax at $15 \%$

Paid as "tax free" dividend, reduces

ACB of shares

Capital Gain on Disposal increased

by (or capital loss reduced by) ${ }^{20}$

Individual Tax Rate (assume 50\%)

Effective Tax Paid

However, in any such situation, the capital gain realization may be deferred, and the resultant tax deferral may represent a substantial saving in tax, if the funds have been effectively utilized in the interim period.

Given the diversity in tax treatment, what are the options available to a shareholder? The shareholder may either take a capital gain, or receive a taxable dividend, or receive a special dividend and take a capital gain. The tax consequences of these various alternatives are analysed below:

Assume a shareholder has an ACB of $\$ 150$, and the corporation has undistributed income on hand of $\$ 100$ per outstanding share. Assume, further, that the shareholder has a marginal rate of $50 \%$.

\section{Alternative 1-Capital Gain}

Shareholder sells shares for $\$ 250$.

Tax on Capital Gain of $\$ 100$

\section{Alternative 2-Taxable Dividend}

Receive $\$ 100$ taxable dividend and

sell shares for $\$ 150$.

Tax paid on dividend

Alternative 3-Part IX Tax and Capital Gain

Receive $\$ 85$ dividend from TPUS after Part IX

tax of $\$ 15$ paid, and sell share for $\$ 150$.

Part IX Corporate Tax

Capital Gains Tax on $\$ 85$

Total Tax

In this particular situation, this shareholder would optimize his tax position by realizing the maximum capital gains possible. However, generalization is not possible in such situations. The answer is dependent, in part, on the individual's marginal tax rate. In higher tax brackets, it is generally better to take capital gains, whereas in the lower tax brackets, it would be preferable to receive normal taxable dividends. rates.

The above cited options are analysed below at various marginal tax

${ }^{20}$ Assuming the price of the shares remain constant, which result may occur if the company is valued on its earnings only. 
Marginal Tax Rates

Options

$30 \% \quad 51 \%$

$62 \%$

1) Capital Gain

2) Taxable Dividend

$\$ 15$

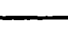

3) Part IX Tax and Capital Gain

5
28

$\$ 25$

33

37

$\$ 31$

47

(c) Capital Structure

As if the above variables were not sufficiently complex, the situation is further complicated by the capital structure of a corporation. In calculating the tax impact of special dividends under 8. 83, paid out of TPUS, due regard must be had for the components of surplus accounts. This is due to the fact that the Part IX-15\% tax is paid only on UIOH in order to convert it into TPUS, but is not payable on 1971 Capital Surplus on Hand [CSOH]. Hence, where a corporation has an equal amount of UIOH and $\mathrm{CSOH}$, the effective special tax is reduced to $7 \frac{1}{2} \%$. In between the two extremes of $100 \%$ UIOH and nil CSOH, and $100 \%$ $\mathrm{CSOH}$ and nil UIOH, there remain a multitude of combinations.

The comparative tax burden on a shareholder receiving $\$ 100$ dividend, from four alternative sources at four different marginal rates of tax, is shown below:

\section{COMPARATIVE TAX BURDEN ON SHAREHOLDERS RECEIVING DIVIDENDS OF $\$ 100$}

Source of Dividend

Type of Structure

Marginal Rates

1) Taxable Dividend

2) Special Dividend

3) Special Dividend 50\% UIOH

4) Special Dividend $100 \% \mathrm{CSOH}$

\begin{tabular}{|c|c|c|c|}
\hline \multicolumn{4}{|c|}{ Marginal Rates } \\
\hline $35 \%$ & $46 \%$ & $51 \%$ & $61 \%$ \\
\hline$\$ 12$ & $\$ 26$ & $\$ 34$ & $\$ 47$ \\
\hline 30 & 35 & 37 & 41 \\
\hline 24 & 29 & 31 & 36 \\
\hline 18 & 23 & 26 & 31 \\
\hline
\end{tabular}

\section{(d) Cash Flow Factor}

In considering the availability of 8.83 dividends to shareholders, it should be observed in passing that the efficacy of any dividend payout policy will depend, in large measure, on the presence of sufficient cash.

\section{Conclusions re Dividends}

Given the above analysis the following conclusions may be put forward as general propositions:

(a) For individuals in the high tax brackets, it is preferable to take a capital gain first, and then to receive a special dividend, even accounting for the reduced ACB of shares. In this tax bracket, the taxable dividend is the least attractive of all alternatives.

(b) For individuals in the lower tax brackets, a taxable dividend is most attractive, then a capital gain and the special dividend is the least attractive alternative.

(c) Again, in the higher tax brackets, a special dividend is always preferable to an ordinary dividend no matter what the composition of the capital structure. In the lower tax brackets, the reverse is true irrespective of the capital structure of the entity. However, in the $46 \%$ to $51 \%$ range of marginal tax rates, the 
situation varies. At a marginal rate of $46 \%$, a special dividend is only preferable if $100 \%$ of the surplus is in CSOH, but not if $50 \%$ only is in CSOH. In contrast, at a marginal rate of $51 \%$, a special dividend is to be preferred, even if there is only $50 \%$ in CSOH and 50\% in UIOH.

\section{Planning Considerations}

As a result of these divergent consequences emanating from diverse personal and corporate situations, it is submitted that the following planning and policy considerations be given due consideration:

(a) Corporate share capital should be divided into different classes and categories. All rights under these various classes may be identical except for dividends. Taxpayers with high marginal rates would receive special s. 83(1) dividends, whilst taxpayers in the lower marginal brackets would receive regular taxable dividends.

(b) The plan outlined in (a) supra, assumes a shareholder composition that remains at approximately the same marginal rate, i.e., either high or low. Caution should be exercised when planning for shareholders whose marginal rates will vary substantially over a period of time. Infants and the elderly are the more obvious examples of this latter category.

(c) By a similar process of analysis, non-residents and exempt organizations may be better served by creating different classes of shares. By virtue of s. 212(2), non-residents are required to pay $25 \%$ withholding tax on account of all taxable dividends paid by corporations resident in Canada. As dividends paid from TPUS are not taxable dividends by virtue of the application of s. $83(i)$ (c), non-residents may receive these amounts without withholding tax. However, where such be the case, they would, in all probability, not have the $15 \%$ Part IX tax recognized as a tax credit in their own jurisdictions. Hence, it may be preferable for non-residents to receive taxable dividends subject to $15 \%$ (until 1976) withholding tax, paid out of post-1971 earnings. By this route, they would claim the withheld tax as a foreign tax credit.

Exempt organizations, as a general rule, will prefer to receive taxable dividends by virtue of their exempt status.

(d) Where high marginal rate taxpayers opt for the special dividends as recommended in (a), supra, they may achieve further tax savings by deferring their capital gains. The magnitude of such savings will depend, in part, on several factors: the prevalent interest rate; the holding period; period of Canadian residence and life expectency, etc.

(e) In making tax computations with respect to available courses of action, shareholders must make some assumptions in respect of anticipated marginal rates in the future. Thus, where such rates are expected to increase, an immediate realized gain may prove expedient. Where they are expected to fall, the converse would hold true. Forecasting future changes in rates, especially over any extended period of time, will, of necessity, be highly speculative. Conceivably, risk models may be used in any such analysis. 
(f) In planning for future capital dispositions, it is imperative that the taxpayer not place himself in a higher marginal tax rate as a consequence of large capital gains in some future period. An orderly disposition of capital holdings, to prevent such adverse consequences, would be necessary.

(g) For shareholders who have marginal rates in the vicinity of 40 to $45 \%$, the immediate saving in tax by receipt of a special dividend may be more than offset by exposure to future capital gains. Taxpayers in this range are particularly vulnerable due to the narrowness of tax brackets at this level.

(h) Consideration should also be given to problems arising from the conversion to new classes of shares to receive special dividends. The newly acquired shares acquired upon exchange will have a cost base equal to the ACB of the shares traded in. As a consequence, regard should be had for the neutral zone rules. As has been pointed out, the neutral zone rules will operate at the time of the exchange and then cease. If fair market value [FMV] is above V-Day values and cost, then a favourable result will ensue since this act will remove any neutral zone restriction on future capital losses. However, adverse consequences flow where FMV is below cost at the time of the exchange. ${ }^{21}$

\section{Dividends Between Parent and Subsidiary}

Where a corporate entity receives a dividend out of TPUS, as opposed to an individual shareholder, the consequences will depend on the nature of the relationship between the two corporate entities. Two possibilities exist:

(a) If the corporation is not controlled, then the special dividend is included in the recipient corporation's TPUS account, and may be passed on to individual shareholders in the same manner as described earlier in this paper. ${ }^{22}$ Hence, the recipient corporation merely acts a conduit between the payor corporation and the receiving shareholder.

(b) Where, however, a Canadian controlled parent receives a special TPUS dividend from a controlled subsidiary, then the parent company has an option available under s. 96(2). The option is to receive a refund of the tax paid by the subsidiary. If the refund is received, then the parent must include 100/15 of the refund in its 1971 UIOH by virtue of s. 196(4)(c). Since the original tax paid is $15 \%$, this results in an amount equal to the aggregate of dividends plus the refund. For examples:

$\begin{array}{lr}\text { Subsidiary has } 1971 \text { UIOH- } & \$ 1000 \\ \text { Part IX Tax } & 150 \\ \text { Parent company receives } & \$ 850\end{array}$

Parent receives $\$ 150$ refund, but must include $\$ 1,000^{23}$ in $1971 \mathrm{UIOH}$.

There is, however, one restrictive condition-a parent corporation must have on hand 1971 Capital Surplus other than 1971 Capital Surplus received from other corporations. The rationale for this restriction is

\footnotetext{
21 Cronkwright, 1972 Conference Report 38.

${ }^{22} \mathbf{S . ~ 8 9 ( 1 ) ( k ) ( i i i ) . ~}$

${ }^{23} 100 / 15 \times \$ 150=\$ 1,000$.
} 
twofold: first, so that corporate shells cannot receive a refund; second, and perhaps more importantly, to discourage the distribution of 1971 Capital Surplus of a parent before $1971 \mathrm{UIOH}$ of the subsidiary has been distributed. This, in effect, equalizes the position of a parent-subsidiary situation with that of a single corporation having the same surplus balances.

The effect of this may be illustrated by the following example:

Assume a single corporation with $\$ 60,000 \mathrm{UIOH}$ and $\$ 40,0001971$ CSOH. Then, the corporation must pay Part IX tax on $\$ 60,0001971$ UIOH before it can pay out capital surplus. ${ }^{24}$ Assume, a multiple chain where the subsidiary has $\$ 60,000 \mathrm{UIOH}$, and the parent has $\$ 40,000 \mathrm{CSOH}$. Without the restriction, the parent could first pay a tax free dividend to shareholders from $1971 \mathrm{CSOH}$, then subsequently receive $\$ 51,000$ from the subsidiary's TPUS and claim a refund of $\$ 9,000.25$

However, notwithstanding the restriction, the parent may well be able to pay all of its $1971 \mathrm{CSOH}$ except for $\$ 1$. Thereafter, it can receive $\$ 51,000$ from its subsidiary's TPUS and claim a refund of $\$ 9,000$.

\section{1971 Capital Surplus on Hand [CSOH]}

\section{(a) Nature of $\mathrm{CSOH}$ :}

Capital Surplus is defined in s. 89(1)(c). In effect, it amounts to the capital gains realized by a corporation prior to January 1,1972 , which could have been distributed. The computation is complex and necessitates the calculation of "tax equity", which is the value of the corporation at tax value and is defined in s. $89(1)(\mathrm{h})$. It will be observed that $1971 \mathrm{CSOH}$ includes pre-1950 undistributed income and consequently benefits older corporations.

\section{(b) Policy and Planning:}

The policy rationale behind $\mathrm{CSOH}$ is to pass through those amounts which were retained under the old system, free of tax e.g., capital gains. The system also benefits shareholders by freeing pre-1950 surplus. As with dividends paid out of TPUS, dividends paid out of 1971 $\mathrm{CSOH}$ are not taxable in the shareholder's hands. However, in contrast to TPUS dividends, since there is no $15 \%$ tax levied on the corporation, if a shareholder's marginal rate of tax is more than $25 \%$, he will prefer a dividend out of $1971 \mathrm{CSOH}$. Where the shareholder's marginal rate is less than $25 \%$, he will prefer a taxable dividend. This compares with a marginal rate of $37 \%$ for dividends paid out of TPUS.

In this regard, the previous recommendation of creating different classes of shares is equally applicable. However, a marginal rate of $25 \%$ is reached relatively early at a taxable income of approximately $\$ 2000$. Further, similar to TPUS dividends, CSOH dividends are treated as a return of investment and reduce the ACB of shares by virtue of $s$. $53(2)(\mathrm{a})(\mathrm{i})$ and s. $83(1)(\mathrm{d})$.

There is, however, a further provision. The $1971 \mathrm{CSOH}$ may be distributed by way of tax free dividend to shareholders, but only after the 1971 UIOH has been converted to TPUS upon payment of Part IX tax. After conversion, under s. 83(1), a special dividend is deemed to be paid

\footnotetext{
2 S. $83(1)$.

2s $15 \% \times \$ 60,000=\$ 9 .(100)$.
} 
out of TPUS first and then out of $1971 \mathrm{CSOH}$, if no contrary specification is made. By virtue of Bill C-170, a corporation may now elect under Part IX to pay tax on the "full amount", although unspecified, of its 1971 UIOH. The s. $83(1)$ is now amended so that it is no longer necessary to designate the amount of any special dividend being paid out of TPUS and $1971 \mathrm{CSOH}$. However, any special dividend paid in excess of available surplus will still attract a $100 \%$ punitive tax penalty.

Given the attractiveness of special dividends in the right circumstances, it will be advantageous for corporations to accumulate as much of $1971 \mathrm{CSOH}$ as is possible. To achieve this objective, corporate tax planners may consider the following possibilities:

(a) As indicated earlier, $1971 \mathrm{CSOH}$ includes capital gains unrealized to December 31,1971, provided they are subsequently realized. Assets sold for less than 1971 values will tend to reduce the amounts in CSOH. Thus, it would be advantageous for a corporation to dispose of those assets which might decrease in value as quickly as possible, if this is operationally feasible. Such assets might include buildings worth more than cost in 1971 but which will decline in value with the passage of time. However, regard should be had for the recapture provisions.

(b) Similarly, where a corporation has both "winners and losers" on hand, it would be desirable to sell the winners and transfer the gain into $1971 \mathrm{CSOH}$. This amount may then be distributed free of tax. At a later time, the losers may be discarded. Since there are no provisions for levying the tax, 1971 capital losses are actually suffered after $1971 \mathrm{CSOH}$ has been fully distributed.

(c) The corporation may consider disposal of its "winners" to a related corporation of which it owns at least $80 \%$ of each class of shares, and thereby benefit by the $\mathrm{s}$. 85 rollover provisions. Hence, where a corporation owns an asset which cost $\$ 100,000$ and had a V-Day value of $\$ 200,000$, it may consider taking the $\$ 100,000$ capital gain into $\mathrm{CSOH}$. If, however, the corporation did not sell, and the value increased to $\$ 400,000$, then in order to realize a gain of $\$ 100,000$ to $\mathrm{CSOH}$, the company would be required to take an additional $\$ 100,000$ taxable capital gain into income and pay full tax rates. Sale to a related corporation and a s. 85 rollover may alleviate this type of problem.

(d) Subject to the provisions in the Act for preventing dividend stripping and artificial transactions, a corporation may be able to generate and utilize $\mathrm{CSOH}$ on more than one occasion and where a chain of corporations is involved, it may be possible to extract the same CSOH, as a "tax free" dividend, two or even three times. ${ }^{26}$

\section{Post-1971 Corporate Distributions}

To this juncture, this paper has examined the distribution of designated surplus and pre-1972 corporate surpluses and the problems associated therewith. The remainder of this paper examines the distribution of post-1971 corporate surpluses.

27 An outline of this technique is illustrated in Appendix C. 
1. Cash Dividends:

The most routine and common of all corporate distributions is the payment of cash dividends. Under s. $12(1)(j)$, any dividends received by the individual shareholder are treated as income. It may be reiterated that, unless an election is made under s. 83 as described earlier, any dividends paid out are taxable dividends. ${ }^{27}$ Where dividends are received from "taxable Canadian corporations", the individual taxpayer brings in the dividend, plus one-third, into income. ${ }^{28}$ The effect of this is illustrated below:

An individual receives a dividend of $\$ 300$ from a taxable Canadian corporation, and has a marginal rate of $40 \%$. Then: ${ }^{29}$

\begin{tabular}{lc} 
Dividend received & $\$ 300$ \\
S. 82(1) & 100 \\
Income declared & $\$ 400$ \\
Tax at 40\% & 160 \\
Tax credit s. 121 & $(100)$ \\
Tax payable & $\$ 60$ \\
\hline
\end{tabular}

The rationale behind this technique is to alleviate, at least to some degree, the burden of double taxation. S. 121 has the effect of achieving a certain measure of integration of corporate and personal income tax. Further, since interest and carrying charges are deductible, but the credit is calculated on the gross amount of the dividend, shareholders should borrow as much as possible to invest in taxable Canadian corporations. The following is an illustration of a taxpayer in the highest tax bracket, receiving a dividend of $\$ 100$, with carrying charges of $\$ 100$ :

Dividend received

Carrying charges

$\$ 100.00$

(100.00)

Net income

S. 82(1)(b) gross up

$\$ \quad 0.00$

33.33

S. 117: Federal tax at $47 \%$

S. 121: Tax credit at $4 / 5$

Provincial tax at $30.5 \%$

Total tax credit

This tax credit of $\$ 14.36$ may be applied against other income.

It is important to note, however, that the effect of cash dividend distributions is not uniform. Different consequences flow if the dividend is received from a Canadian controlled public corporation [CCPC], or a public corporation, active business income, or investment income. Thus, in the case of an individual taxpayer in the 60\% marginal tax bracket, receiving $\$ 10,000$ of active business income, through the medium

\footnotetext{
27. S. 89(1)(j).

2. S. 82(1).

Short form method, cumbining Federal and Provincial credits.
} 
of either a public corporation or a CCPC, the following results would flow:

Active business income

Tax payable by corporation

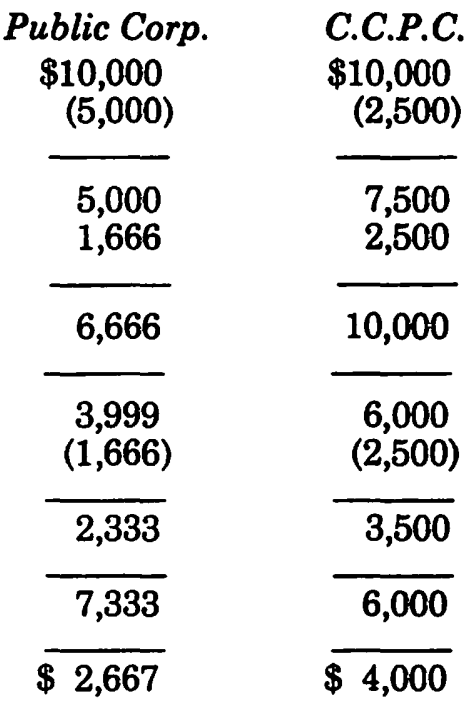

Tax at $60 \%$

S. 121 dividend tax credit (short form)

Tax payable by shareholder

Total tax paid on original earnings

Net after tax to shareholder

mount paid to shareholder

S. 82(1) gross up

Taxable income

2. Tax Planning

Given the above analysis, it may be observed that there is complete integration of taxes for the CCPC and the individual shareholder. However, for any corporation that is taxed at maximum rates, it would be better for an individual to receive funds by way of salary rather than dividends. The tax on $\$ 10,000$ salary, at $60 \%$, would be $\$ 6,000$, as compared with $\$ 7,333$ when received through a corporation.

Again, for those taxpayers in the higher tax brackets, it may be advantageous if the corporation retained the money. There are two ways in which the advantage would accrue: (a) lower taxes-assuming the corporation in the previous example had retained the $\$ 5,000$ dividend, and this had been reflected in the price of its shares:

\begin{tabular}{lr} 
Capital gain & $\$ 5,000$ \\
Taxable capital gain & 2,500 \\
\hline Tax at 60\% & 1,500 \\
Tax paid by corporation & 5,000 \\
Total tax paid & $\$ 6,500$
\end{tabular}

This is still lower than the $\$ 7,333$ tax paid, if the dividend had been received through the corporation, but higher than the tax if the amount had been received by way of salary. (b) Deferment-where the shares are not sold, but retained by the shareholder, there is a further advantage gained through the deferral of taxes. The magnitude of the advantage is dependent on the length of the holding period, interest rates, future marginal tax rates, etc. 


\section{Conduit Corporations}

Where a shareholder receives a dividend from a corporation, which has previously received a dividend from another corporation, ${ }^{\prime \prime \prime}$ then Co. B merely acts as a conduit and the shareholder is in the same position as if he had received the dividend directly from Co. A. Once again, the rationale is to prevent multiple taxation of the same funds. This effect of this flow through may be seen below:

Dividend received

Tax payable s. 112(1)

Part IV tax s. 186(1)

Amount available for dividends

Tax refund

Dividend paid

S. 82(1) gross up

Tax at $40 \%$

S. 121 credit (short form)

Tax payable
Public Corp. $\$ 60,000$

C.C.P.C.

$\$ 60,000$

\begin{tabular}{|c|c|}
\hline$\overline{-}$ & $(20, \overline{0} 00)$ \\
\hline $\begin{array}{c}60,000 \\
-\end{array}$ & $\begin{array}{l}40,000 \\
20,000\end{array}$ \\
\hline $\begin{array}{l}60,000 \\
20,000\end{array}$ & $\begin{array}{l}60,000 \\
20,000\end{array}$ \\
\hline 80,000 & 80,000 \\
\hline 32,000 & 32,000 \\
\hline$(20,000)$ & $(20,000)$ \\
\hline$\$ 12,000$ & $\$ 12,000$ \\
\hline
\end{tabular}

\section{Capital Dividends}

This concept of integration is further seen in the private corporation situation, when one examines the treatment of capital gains flowing through a private versus a public corporation. S. $83(2)$ is intended to effect an integration of the taxation of capital gains at the level of both the corporation and individual Canadian resident shareholders. The impact of taxes on a $\$ 100,000$ capital gain received through a public versus a CCPC shareholder, who has a $40 \%$ marginal rate is shown below:

Capital gain

Taxable portion s. 38

Tax payable

Refundable portion s. 129

Amount in capital dividend account

Amount available for dividend

Tax free portion to shareholder

S. 83(2)(b)

\section{Public}

$\$ 100,000$

\begin{tabular}{|c|c|}
\hline 50,000 & 50,000 \\
\hline $\begin{array}{c}25,000 \\
-\end{array}$ & $\begin{array}{l}25,000 \\
12,500 \\
50,000\end{array}$ \\
\hline $\begin{array}{l}75,000 \\
-\end{array}$ & $\begin{array}{l}87,500 \\
\overline{50,000}\end{array}$ \\
\hline
\end{tabular}

Private $\$ 100,000$

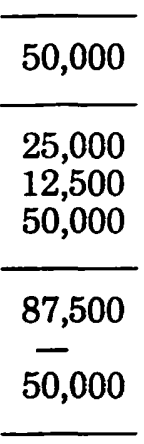

iw E.g., Co. A to Co. B to shareholder. 
Taxable to shareholder

\begin{tabular}{|c|c|}
\hline 75,000 & 37,500 \\
\hline 25,000 & 12,500 \\
\hline 100,000 & 50,000 \\
\hline $\begin{array}{c}40,000 \\
(25,000)\end{array}$ & $\begin{array}{c}20,000 \\
(12,500)\end{array}$ \\
\hline $\begin{array}{l}15,000 \\
25,000\end{array}$ & $\begin{array}{r}7,500 \\
12,500\end{array}$ \\
\hline 40,000 & $\$ 20,000$ \\
\hline
\end{tabular}

If the individual shareholder had received the $\$ 100,000$ capital gain directly he would have paid $\$ 20,000^{31}$ total tax. The amount of the capital dividend does not reduce the ACB of shares held. ${ }^{32}$

From a tax planning point of view, it is essential that where a company is being wound up, care should be taken to realize the capital gains prior to the wind up, or else the right to make the election to pay a capital dividend is lost. Further, because of the changes introduced by Bill C-170, a private corporation paying a capital dividend under s. 83(2) is no longer required to distribute all its TPUS first. However, the corporation should still convert its 1971 UIOH into TPUS by paying the $15 \%$ special Part IX tax, if it is to avoid the $100 \%$ penalty on an excessive election.

\section{Refundable Dividend Tax}

This tax, which is levied by virtue of s. 186 and s. 187 (Part IV), is applicable to dividends received from a taxable Canadian corporation by a private Canadian corporation. The system taxes shareholders of closely held corporations in respect of investment income received. Since the concept of "personal corporations" was abolished under the new Act, this new concept is an integral part of the new system.

The $\operatorname{tax}$ in question is $33-1 / 3 \%$ of the amount of taxable dividends received and deductible by the corporation in computing its taxable income under s. 122(1). The intent is to promote the flow-through of investment income and put the shareholder in the same position as if he would have received the income directly. Hence, the figure of $33-1 / 3 \%$, which is the equivalent of what an individual taxpayer in the $50 \%$ bracket would pay if he received the income directly. For example:

$\begin{array}{lr}\begin{array}{l}\text { Dividend } \\ \text { Gross up }\end{array} & \$ 750 \\ & \\ & \\ & \\ & \\ & \\ & \\ & \end{array}$


Tax at $50 \%$

Tax credit

Tax payable

Hence, if an individual's marginal rate is in excess of $50 \%$, it would be to his advantage to leave his portfolio in a private corporation. In contrast, if his marginal rate is less than $50 \%$, he would be better off taking his money out.

As the name implies, the tax is a refundable tax. Under s. 129 , the tax is refunded at the rate of $\$ 1$ for every $\$ 3$ of dividends paid out by the corporation. In this manner, the tax is completely integrated with that of the individual:

Corporate investment dividend

Refundable tax paid at 33-1/3\% under s. 186

Funds retained

Corporation pays dividend of

\begin{tabular}{lr} 
Funds on hand & $\$ 500$ \\
Refund s. 129 & 250 \\
\hline
\end{tabular}

It should be noted that the refundable dividend tax is not applicable to special dividends paid out of TPUS or $1971 \mathrm{CSOH}$.

In this context, the tax planner should be alert for the possible effects of s. 129(1) and s. 129(3). The refund is only available to a company that was a private corporation at the end of any taxation year. Hence, if a private company becomes public, the refund is lost forever, since even if it reverted back to the status of a private corporation, $\mathbf{s}$. 129(3) would apply to compute its refundable tax on hand from the date it last became a private corporation.

\section{CONCLUSION}

The reader of this paper will have become aware of the intricacies of the new Income Tax Act in its provisions relating to corporate distributions to stockholders. To observe that the legislation in this regard is complex is merely to state the obvious. The writer has attempted to analyze the tax implications of corporate distributions in the areas of designated surplus, post- and pre-1972 distributions, and the resulting consequences on stockholders. That there is no panacea for tax planning is obvious from the diversity of the variables examined. Each tax plan must attempt to balance the requirements of the corporation's capital needs, the individual taxpayer's personal financial status, and his long-term objectives. 
APPENDIX A

\section{ILLUSTRATION OF A "BROKER BAIL OUT"}

Facts:

Company A with a surplus of $\$ 100,000$ is owned by one shareholder B.

Method:

(a) Shareholder B sells his shares to a broker $Y$ for $\$ 100,000$.

(b) Broker Y, new owner of shares, gets Co. A to pay him a dividend of $\$ 100,000$. This dividend is taxable since it has been paid out of designated surplus, created upon change of control.

(c) Broker Y sells back the shares to B for $\$ 1$, thereby creating an inventory/trading loss of approximately $\$ 100,000$.

(d) At this stage, Broker Y's position is as follows:

Income (dividend from designated surplus) $\quad \$ 100,000$

Trading loss

Taxable income

$\$ 0$

Results:

(e) Shareholder B has his $\$ 100,000$ tax free (no capital gains tax prior to 1972) and his shares.

(f) Co. A has been effectively stripped of $\$ 100,000$ of designated surplus.

(g) Broker $\mathrm{Y}$ is wealthier to the extent of his commission.

\section{APPENDIX B}

\section{ILLUSTRATION OF EXTRACTION OF SURPLUS THROUGH A HOLDING COMPANY}

Facts:

Co. Y, with undistributed income of $\$ 100,000$, is owned by Co. X, the latter company having no undistributed income on hand.

Method:

(a) Co. I buys out the shares of Co. X. Since Co. X has no UIOH, there is no surplus to designated;

(b) Control of Co. Y has not changed and, hence, its surplus is not designated;

(c) Co. Y pays a dividend to Co. $X$, with no tax payable since this is an intercorporate dividend.

(d) Co. X pays a dividend to Co. Z, with no tax payable since payment is out of control period earnings.

Result:

Co. Y has been stripped of its $\$ 100,000$ UIOH. 
APPENDIX C

ILLUSTRATION OF EXTRACTION OF CAPITAL SURPLUS

Assume there are three corporations, A, B and C, with the following ownership structure:

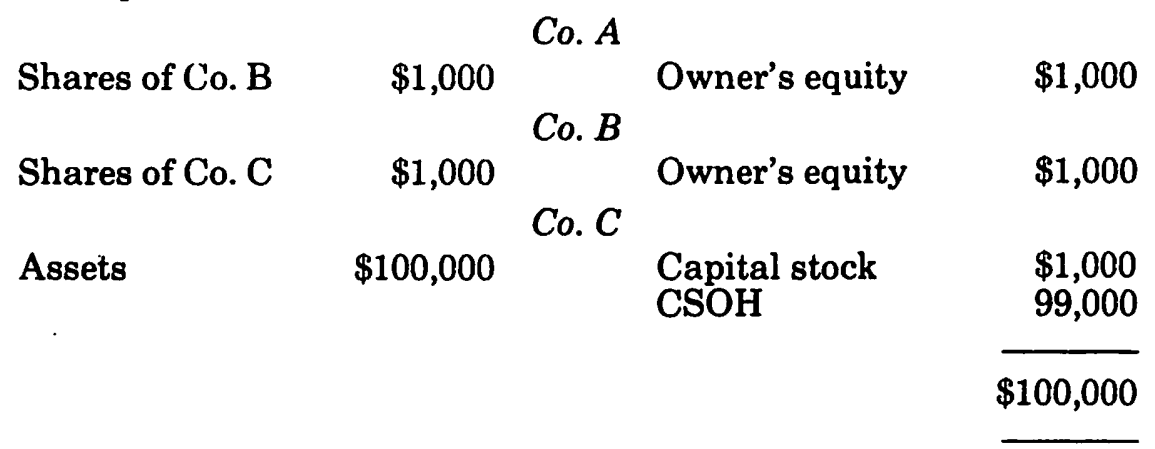

Thus, Co. A owns $100 \%$ of Co. B, and Co. B owns $100 \%$ of Co. C. Assume, further, that $\mathrm{Co} . \mathrm{C}$ is a profitable enterprise and has a value of $\$ 100,000$ on V-Day. Given these facts, the following transactions may be entered into:

(a) Co. A sells its holdings of Co. B to a new Co.-Co. M (which company has the same shareholders as Co. A) for $\$ 200,000$, in return for a note. Then, Co. A has $\mathrm{CSOH}$ of approximately $\$ 200,000$.

(b) Co. C pays its profits to Co. B, and finally to Co. M, and the latter company pays off the note to Co. A.

(c) Co. A now distributes a $\$ 200,000$ tax free dividend to its shareholders. Then the $\mathrm{ABC}$ is reduced to nil.

(d) Now Co. B sells its holdings of Co. C to Co. A for $\$ 200,000$ in return for a note. Co. B has CSOH of $\$ 200,000$.

(e) Co. C pays dividends to Co. A, and the latter company pays off its note to Co. $B$.

(f) At this point, Co. B distributes $\$ 200,000$ to its shareholders as a tax free dividend, but $\$ 100,000$ is taxed as a capital gain: $60 \%$ (assumed tax rate) $\times \$ 100,000=\$ 60,000$.

(g) Co. C is now wound up, and the $\$ 100,000 \mathrm{CSOH}$ is distributed tax free. Once again, this is taxed: 60\% (assumed tax rate) $\times$ $\$ 50,000=\$ 30,000$.

(h) Thus, the total capital gains tax paid is:

$\begin{array}{lr}\text { Step (f) } & \$ 60,000 \\ \text { Step (g) } & 30,000 \\ & \$ 90,000\end{array}$

(i) However, $\$ 400,000$ has been extracted from the companies, which would have involved a total tax of: $60 \%$ (assumed tax rate) $\times$ $\$ 400,000=\$ 186,666$. 